\title{
Settlement agreements, legal information and the mistake of law rule in contract
}

\author{
DAVID COLLINS*
}

City Law School, University of London

\begin{abstract}
The extent of the doctrine of contractual mistake of law is evaluated in light of the Court of Appeal's decision in Brennan $v$ Bolt Burdon through the lens of economic efficiency, the associated incentivisation of productive information acquisition and contractual risk allocation. The Brennan court's decision limits the relief available for claims of mistake grounded in unanticipated changes in the law to mistakes involving exceptional errors. In so doing it acknowledges the risk inherent in accepting contractual settlement offers as a matter of commercial risk taking which can be offset through express contractual limitation, subject to public policy concerns. The article considers the effects of such contractual risk allocation as well as the cost of dispelling ignorance to recommend a clarification of the scope of the mistake of law. This rule is based upon the gains to be achieved from the underlying contract to the contractual parties as well as advantages to society engendered by the dissemination of information about the law itself.
\end{abstract}

\section{Introduction}

Tn entering a contract for the settlement of a civil claim based upon the perception that Ithe suit may fail due to the status of a particular precedent or statutory provision, both the claimant and the defendant undertake the risk that the law may not be as they understand it to be and consequently their decision to abandon a claim or defence may be unwise. A wide ambit for the doctrine of mistake of law could vitiate this concern, allowing parties to renege on such agreements when based upon flawed assumptions about the ongoing validity of the law. In so doing, the precise application of this doctrine will have significant effects upon the behaviour of settling parties, most notably those attempting to reach a pre-trial compromise in litigation. This behaviour may have effects beyond the particular transaction because of the important role legal information plays in society.

This article will consider the scope of the mistake of law rule in contract from an economic perspective. It will analyse the ways in which a narrow interpretation of this rule, as seen in the Court of Appeal decision in Brennan $\mathrm{v}$ Bolt Burdon, ${ }^{1}$ may affect both the acquisition of productive information and foster contractual risk allocation, ultimately

\footnotetext{
* Senior Lecturer, City Law School, City University London, BA, JD (Toronto), MSc, BCL (Oxon). Email: david.collins@utoronto.ca. The author would like to thank Michael Knoll of the University of Pennsylvania for helpful comments on an earlier draft.

1 [2004] EWCA Civ 1017 (hereinafter Brennan).
} 
contributing to the enhancement of social welfare. The discussion will offer a more clearly delineated test for the mistake of law rule in contract that explicitly takes into account the costs of resolving uncertainty and more complete contract drafting compared to the gains of underlying transaction, which include the avoidance of trial in the case of settlements as well as the dissemination of useful information regarding the law. This article will not examine restitutionary mistake, such as that involved with the payment of money based upon mistake. ${ }^{2}$ Rather it will draw upon economic concepts to focus on the entrance into litigation settlement agreements grounded in a mistaken understanding of the law, as seen most clearly in the context of litigation settlements as in Brennan. Before we consider the scope of the rule in light of this decision, it is necessary to review the economic rationale which underlies the doctrine of mistake in contract law.

\section{Mistake and the social welfare of productive information}

In assessing the efficiency of legal rules regarding mistake in contract, scholars have drawn a distinction between mistakes which are based upon a lack of information that could have been obtained through effort (productive information) and those based upon mistakes resulting from a lack of information that could have been casually or fortuitously acquired (non-productive or re-distributive information). ${ }^{3}$ The former type of information is productive in that it can be used to generate greater wealth for society by allowing existing uses of goods or property to be shifted to more productive ones, such as farmland being used for oil drilling. In contrast, ordinary factual information is often merely re-distributive in that it can only be used to allocate wealth in favour of the informed party - it does not add to the knowledge base of society and as such does not improve social welfare. The logic of this distinction was noted by Kronman as the reason for the lack of a general duty to disclose relevant facts in the law of contract, allowing parties to profit from their superior knowledge. ${ }^{4}$

The concept of productive information is not without its critics, for example, Trebilcock has argued that the generation of allegedly productive information may lead to a waste of resources because it may already be held by others and may also be transmitted at low cost. ${ }^{5}$ In the case of legal information, this may equate to researching a legal issue, the answer to which is already widely known.

Still, in conventional economic theory as first postulated by Rasmusen and Ayres, it follows that relief should be granted for mistake if the gains from trade for mistaken parties are negative or where the care to avoid mistake was merely re-distributive rather than productive. ${ }^{6}$ Mistake should be found where it was based on useless information, because it would have been a waste of resources to obtain it. In the context of a settlement agreement in litigation, a negative gain will occur where the quantum of the settlement predicated upon a mistaken understanding of the law falls short of the amount that would

2 There is a substantial amount of scholarship on this topic: e.g. R Williams, "Beginnings of a public law of unjust enrichment" (2005) 16 KCLJ 194; M de Gregorio, "Impossible performance or excused performance - common mistake and frustration after Great Peace Shipping” (2005) 16 KCLJ 69; D Friedman "The objective principle and mistake and involuntariness in contract and restitution" (2003) 119 LQR 68.

3 E.g. A Kronman, "Mistake, disclosure, information and the law of contracts" (1978) 7 J of Legal Studies 1; J Smith and R Smith, "Contract law, mutual mistake and incentives to produce and disclose information" (1990) 19 J of Legal Studies 467; E Rasmusen and I Ayres, "Mutual and unilateral mistake in contract law" (1993) 22 J of Legal Studies 309; R Cooter and T Ulen, Law and Economics 4th edn (London: Pearson 2004), p. 281.

4 Kronman, "Mistake", n. 3 above.

5 M Trebilcock, The Limits of Freedom of Contract (Cambridge, Mass: Harvard UP 1993), p. 112.

6 Rasmusen and Ayres, "Mutual and unilateral mistake", n. 3 above, at p. 339. See also C Veljanovski, Economic Principles of Law (Cambridge: CUP 2007), p. 146; Cooter and Ulen, Law and Economics, n. 3 above, at p. 281. 
have been awarded at trial, taking into consideration the foregone cost of that trial. This represents a failure to compensate claimants properly for the injuries they have sustained. In other words, mistake is paying too much or receiving too little because of a misunderstanding of one's legal rights.

However, the distinction between productive and redistributive information is largely inapplicable in the case of mistake of law because of the inherent worth in all information about the law. Acquisition of legal knowledge can be seen as the most valuable type of information because it has the potential to affect the rights of a wide segment of society, unlike information about a particular traded asset, even one that may generate vast quantities of wealth such as an oilfield, as in the example noted above. Likewise, legal research is the most productive labour undertaken by lawyers because the effort does not need to be repeated for every client, unlike, for example, work involved in familiarising oneself with a particular set of facts, such as a client's assets or liabilities. Of course, legal knowledge must be adapted somewhat to fit each client's particular fact scenario and this can be quite time-consuming. Since the law should encourage activities that enhance social welfare, a transaction founded upon a mistake induced through one party's failure to seek information about the law could be viewed as efficient in that it will incentivise greater investigation into the law for the benefit of all. Denying mistake in such circumstances will promote future aggregate social gains in terms of knowledge of precedent acquired for subsequent use, even though one party might lose out in the transaction at hand. ${ }^{7}$ In a sense, though, such information is merely distributive rather than productive - the information was not unknown generally, just unknown to certain individuals. The social utility must be viewed in light of the, admittedly discredited, declaratory theory of law, which posits that the law has always existed and as such legal information can never really be "created" in the sense that ordinary information can. Legal information can still be uncovered and clarified through research and re-litigation.

Economic theory also suggests that for the sake of efficiency the law should assign liability for mistaken assumptions of law or fact to the party who can insure against the contingency at least cost. ${ }^{8}$ This is because contracting parties should allocate the risk of mistake occurring to the party that can obtain information most easily and in so doing minimise the joint costs of contracting. ${ }^{9}$ It is necessary to determine which party was better placed to obtain the information the lack of which led to the mistake. Information that might be available by chance to one party may require effort of another party to be obtained due to their relative endowments or position. Since they have possession, sellers of goods are generally seen as better able to acquire knowledge about the traded good and therefore their informational costs will be lower than those of the purchaser. Trebilcock's contention that inequality is balanced by the purchaser's superior knowledge with respect to the planned use for the good ${ }^{10}$ is untenable as we should expect that planned uses are either obvious or else disclosed to ensure suitability for purpose. The law should therefore uphold mistakes on the part of purchasers regarding some feature of the good in question. ${ }^{11}$

7 This is Kaldor-Hicks efficiency: any change to the situation will in aggregate generate more losses than gains. See e.g. A Ogus, Costs and Cautionary Tales (Oxford: Hart 2006), pp. 26-31.

8 Cooter and Ulen, Law and Economics, n. 3 above, at p. 278.

9 Kronman, "Mistake", n. 3 above, at p. 4.

10 Trebilcock, The Limits, n. 5 above, at p. 140.

11 The opposite conclusion was reached in the US case Sherwood v Walker 66 Mich 56833 NW 919 [1887] where the seller was able to void the sale despite being in a better position to know that the traded good (a pregnant cow) was more valuable than both parties had originally thought. 
Such logic should not strictly apply to settlement agreements which can be voided for mistake of law. While both the seller (the claimant) and the purchaser (defendant) hold private factual information regarding the strength of their respective cases, regardless of the law's attempt to correct this mutual uncertainty through disclosure rules, the law in question is common to both sides and publicly available. Relative endowments are more relevant to mistake of law in as much as wealth will augment the accessibility of legal information through the greater affordability of comprehensive legal research. This must be viewed in light of the fact that defendants (such as manufacturers) will have a greater incentive to investigate the law relating to a particular issue than will a single claimant victim because similar lawsuits will likely arise again. For some parties the burden of obtaining the necessary information to eradicate a mistake of law might exceed the efficiency gain from the transaction itself. The commercial unacceptability of this cost imbalance can be presumed via the doctrine of revealed preferences: a party prefers to incur the risk of transacting in absence of knowledge rather than incur the high cost of obtaining information. As such they are said to be rationally ignorant. ${ }^{12}$

The decision not to contract around risk of mistake of law, or to avoid it through research may again simply demonstrate the parties' endowments - a wealthier party is better placed to engage in speculative litigation based on an uninvestigated legal principle. ${ }^{13}$ This could be equally indicative of the attitudes towards or understanding of risk on the part of the trading parties. As Kahneman's concept of cognitive bias indicates, ${ }^{14}$ a decision such as whether to settle a claim or negotiate to avoid the risk that it will be avoided may be the result of "bounded rationality". For example, a solicitor or his or her clients may suffer from an irrational incapacity to appreciate that an apparently established precedent could have been overruled because this has not been directly observed by them before, whereas the burden of personally experienced past litigation costs (or failures at trial or appeal) as alternatives to settlement are much more real and memorable. ${ }^{15}$ Such inexperience is as much a feature of professional skill as is proficiency in legal research, but importantly it should be reflected in the price of the legal services, such that it can be properly assessed as a transaction cost.

The extent to which courts have evaluated these risks of uncertainty in the rules for mistake of law will now be considered in light of the most recent English case on mistake of law in contract, Brennan $\mathrm{v}$ Bolt Burdon.

\section{Brennan and mistake of law}

The Court of Appeal decision in Brennan $\mathrm{v}$ Bolt Burdon examines the extent to which a claim of common mistake of law (both parties make the same mistake) can operate to void a contract, a principle that had been previously established in Kleinwort Benson Ltd v Lincoln City Councill $^{16}$ in relation to restitutionary claims for the payment of money by mistake. In Brennan, the claimant was a tenant who had suffered personal injuries due to the inhalation of carbon monoxide which had resulted from the faulty operation of a boiler in the

12 This has shown to be particularly true in the case of online purchasers: R Hillman, "On-line boilerplate: would mandatory website disclosure of e-standard terms backfire?” in O Ben-Shahar (ed.), Boilerplate: The foundation of market contracts (Cambridge: CUP 2008).

13 This ignores the fact that wealthy parties have more to lose in litigation than poor ones.

14 D Kahneman, P Slovic and A Tversky, Judgment under Uncertainty: Heuristics and biases (Cambridge: CUP 1982).

15 This phenomenon is known as the "availability heuristic".

16 [1998] 4 All ER 513. BP v Aon Ltd [2006] EWHC 424 (Comm) suggests that there remains a substantial doubt as to whether Kleinwort applies to a contract entered into under a mistake of law (although this case did not refer to Brennan). 
defendant Islington Council's premises during two periods of time in the 1990s. The claimant had instigated an action against the defendant but, due to an oversight by her solicitors, the claim form was not served within four months of the date of issue, in violation of the Civil Procedure Rules (CPR), Part 7, r. 5(2). Consequently, the defendants filed a motion under CPR, Part 11, r. 1, to have the claim set aside as out of time. The application was duly granted by the recorder who relied on two Court of Appeal judgments relating to the extension of time for service. ${ }^{17}$ But before the initial claim was set aside the claimant had already launched a second action against Islington relating to the second period of time during which the boiler had caused her injuries. After the recorder's decision to set aside the first action on the grounds of breach of the CPR's timeframe, the defendant's solicitor requested that the claimant's solicitor discontinue the second action, arguing that it was inevitable that it would also be set aside for delay given that the claim form in the second action had also been served past the relevant deadline. The claimant's solicitor agreed in writing to discontinue the action provided that the defendant would not make an order for costs such that each side would be responsible for its own costs only. In essence the settlement contract was predicated upon the shared assumption that the law as it stood dictated that the claims would be stricken for delay.

However, unknown to both parties, one of the authorities ${ }^{18}$ on which the recorder had relied in her dismissal of the original action as out of time had actually been reversed by the Court of Appeal before the settlement agreement had been concluded, the result being that the service of both claims had actually been valid. Brennan appealed the recorder's decision, arguing that that the compromise agreement was void for a common mistake as to law. The defendants asserted that their settlement agreement was binding and applied to the court to stay this appeal of the first action until Miss Brennan performed her agreement to discontinue the second action on the basis that each party would bear its own costs. This application was refused and the appeal of the first action eventually came before the Court of Appeal.

According to Maurice Kay LJ the central matter at issue was whether the compromise of proceedings entered into by the parties on the basis of common mistake of law was void by reason of that mistake. Acknowledging Kleinwort, the court re-iterated that a common mistake of law may now render a contract void. Furthermore, under Huddersfield Building Company Ltd v Henry Lister \& Son Ltd, ${ }^{19}$ a compromise in litigation is a contract to which the ordinary rules of contract law apply and, indeed, it can be set aside due to mistake. Relying on The Great Peace, ${ }^{20}$ which established that for a common mistake to be operative it must render performance of the contract impossible, Maurice Kay ruled that the court's acceptance of the service past the due date was not truly impossible, as there was a chance that the court might have interpreted the relevant caselaw in a more lenient fashion: there would be a small but statistically significant chance of persuading the court to take a different view regarding delay of service. This probability of success fell considerably short of the unequivocal result flowing from mistake outlined in Kleinwort as well as Great Peace's need for impossibility. The fact that Brennan's solicitor did not even inquire as to whether the relevant authority regarding extension of time for service was

17 Godwin v Swindon Borough Council [2001] 4 All ER 641 and Anderton v Chyd County Council [2001] EWHC QB 161.

18 Anderton v Clwyd County Council [2001] EWHC QB 161. This case was unreported at the time of contracting according to A Burrows, A Casebook on Contract (Oxford: Hart 2007), p. 638.

19 [1895] 2 Ch 273.

20 [2002] EWCA Civ 1407 (hereinafter Great Peace). The unstated logic of this principle must be that a contract that is impossible to perform will obviously consume greater resources in the performance than it will produce in the execution because the execution will not take place. 
under appeal or not was taken by Maurice Kay to indicate that there was a general lack of prudence on the part of the promisor and that the court should be "reluctant to countenance as a mistake of law a situation in which it is generally known or ought to be known that the law in question is about to be reconsidered on appeal". ${ }^{21}$ Thus Brennan was seen to have born the risk that the assumption was untrue. This encapsulates the obvious difference between the case in which a lawyer overlooks a decision of the Court of Appeal and one in which the lawyer reads the cases accurately but fails to anticipate that the decision being relied upon will be overturned.

It is Maurice Kay's and Bodey LJ's comments regarding this assumption of risk in contractual relations that is most telling with respect to the economic rationale underpinning the court's decision. Drawing upon the dicta in Great Peace which referred explicitly to the need to identify which party has undertaken the risk that a contract will become impossible to perform, Maurice Kay stated:

where a party wishes to reserve his rights in the event of subsequent judicial decision in a future case to which he is not a party, it is he who should seek and secure a term to that effect, not his opponent who should have to stipulate for protection notwithstanding the possibility of such a subsequent decision. Such a requirement is consistent with the policy of encouraging settlements and respecting their finality. ${ }^{22}$

He concluded by classifying the situation underlying the compromise agreement as a state of doubt rather than as a true mistake of law. ${ }^{23}$ The risk of a future judicial decision which could be advantageous to his client was impliedly accepted and bargained away by the claimant's solicitor. Bodey stated that it is the nature of contractual transactions, such as compromise agreements in litigation, that "both parties recognize the risk that their opinions as to the point of law in question may not be right" and that later judgments may be issued which "render erroneous a former interpretation of the law which had seemed to be sound". ${ }^{24}$ Quoting from Kleinwort, Bodey emphasised that a person who performs a contractual obligation when in doubt as to whether there is a requirement to do so (by either law or fact) assumes the risk of being wrong as an inescapable vagary of the common law tradition. As Peel justly notes, ${ }^{25}$ Bodey's comments hint at the absurdity of the declaratory theory of law. Bodey goes on to state that there is no operative mistake if one party can be said to have borne the risk that the parties might be mistaken in some way.

Although the claimant's solicitor's decision to engage in the second suit at all was based upon imperfect information (it was unknown at the time that the recorder would dismiss the first claim as out of time), Maurice Kay cautions that the reliability of the information on which this decision was based could have been augmented by further inquiry into the status of the precedents at issue. Specifically, the solicitor could have learned whether the judgment upon which the recorder relied was currently before a higher authority and therefore more susceptible to reversal. However, as we shall see, this investigation would represent a further transaction cost which could either impair the settlement process or negate the benefit of avoiding greater litigation costs as Brennan had hoped to achieve.

21 Para. 20.

22 Para. 22.

23 The practical difference between these two concepts is unclear as there is always some doubt regarding a lower court's decisions which can be readily overruled. There may be less doubt with respect to a statutory law, which although susceptible to repeal, may carry the perception of greater permanency.

24 Para. 31.

25 E Peel, Treitel: The law of contract (London: Thompson Sweet \& Maxwell 2007), p. 326. 


\section{Contractual risk allocation and pricing of legal claims}

Bodey's final remarks in Brennan illuminate the crucial role that the law plays in ascribing default terms to contracts and the implications in terms of allocative efficiency. According to him, if parties wish to accommodate the possibility that the law will change subsequent to the commencement of contractual relations then it is up to parties themselves to provide for this in the contract itself. ${ }^{26}$ The opposite conclusion - that an express provision is needed specifically to permit the contract as written to stand in the event of a change in the law - is quite rightly seen as absurd. These statements implicitly acknowledge the Coase theorem: the efficient outcome will be achieved irrespective of the law through negotiation between the parties. However, the truth of Bodey's assertion, and indeed of the Coase theorem, depends on an assessment of the expense of including a clause such as this one in settlement agreements, as indeed in any other contract, a classic transaction cost. It is by no means clear that the ex ante legal costs of negotiating such a term into a compromise agreement would outweigh the gains of avoided disputes. Efficient contracting would be more likely were solicitors to use standard form compromise agreements that are exhaustive in their coverage because the marginal cost of so doing would decrease the number of situations in which such contracts were implemented. In these situations, the removal of a standard clause expressly negating the effect of any future changes in the law could further be used as a bargaining chip in the attainment of a more favourable settlement agreement or indeed a lower-priced good. ${ }^{27}$ Clearly, the allocation of risk of mistake of law through express contractual provision will occur when contracting parties see this as the cheapest way of avoiding the risk, the only alternative risk-limiting option being the acquisition of information about the true status of the law to the point of near certainty, as we will see below.

The extent to which mistake of law or fact will be countenanced by a court in the absence of contractual stipulation may depend on the subjective perception of risk on the part of the party making the claim, which, as we have noted above, may be irrationally founded. Burrows holds that a party making a claim for mistake should only be denied recovery where, at the time of contracting, the party thinks that the facts are probably as they are in truth but contracts anyway, essentially meaning that the party had taken a substantial risk that what he or she thought was the actually truth would not be divulged. ${ }^{28}$ Virgo takes a harsher view, suggesting that there should be no relief where the claimant was even aware that there was a possibility of being mistaken. ${ }^{29}$ This latter approach appears to echo Bodey's view that any suspicions regarding the veracity of law or fact should be reflected in the text of the contract itself. It is perhaps, however, inapplicable in the context of mistake of law because of the nature of the system of precedent which by its nature obviates absolute certainty in the law at a given time, despite the declaratory theory of law's fiction of permanence in the law, if not in its interpretation.

Bodey notes a further practical difficulty that would result if the conclusion that mistakes relating to the understanding of law would permit the avoidance of contractual obligations were to stand. Inevitable uncertainty would be injected into all contracts because of the natural fluctuations in the law resulting from appeals to successive levels of court.

26 A point noted also by Sedley at para. 61. Such "stabilisation clauses" are common in international investment contracts: S Subedi, International Investment Law: Reconciling policy and principle (Oxford: Hart 2008), at p. 159.

27 See, generally, J S Johnston, "Cooperative negotiations in the shadow of boilerplate" in Ben-Shahar, Boilerplate, n. 12 above.

28 Burrows, Casebook, n. 18 above, at p. 140.

29 G Virgo, The Principles of the Law of Restitution (Oxford: Clarendon Press 1999), p. 161. 
This observation is tied to the understanding of legal claims as commodities which can be traded, an analogy reflected to an extent in the contract principle that forbearance from suit is good consideration. Legal claims are thus highly price-elastic - whether or not a settlement is reached is highly contingent upon the quantum requested. ${ }^{30}$ Any indeterminacy in the valuation of these "goods" because of their potential to be rendered baseless through a change to the law represents what is aptly termed market failure. Legal claims will not be traded, and there will be no settlements, because it will be nearly impossible for sellers or buyers to ascribe any value to them. Of course claims are not actually bought in an open market because in a settlement negotiation there is only one buyer (the defendant) and one seller (the claimant). Legal claims are thus highly price-elastic - whether or not a settlement is reached is highly contingent upon the quantum requested. 31 There is consequently no price-setting competition except possibly that reflected in a single defendant's decision to allocate its limited resources to settle a particular claim amongst a series of claims from several claimants, a situation that is not unrealistic given the exposure of large corporations to numerous consumers. With deficient price signals for claims resulting from legal uncertainty, the only way to set a price would be to do so contingently, perhaps by multiplying the sterling sum of the claim by the probability that it is based upon a law that will not be overruled. Given the expected high propensity for error in such calculations it can be suggested that if the law wishes to facilitate settlements as a means of reducing the strain on the civil justice system, ${ }^{32}$ then the market for claims must not be any more volatile or speculative than it is already. This leads to the unsurprising conclusion that the ambit of mistake of law must be attenuated, as the Brennan court appeared to do.

Uncertainty caused by the freedom of a party to escape a compromise agreement arguing mistake of law adds another layer of complexity to the strategy involved in negotiating the terms of a contract. This risk allocation also affects the decision whether to extend or accept an offer to settle. Such processes have been evaluated under game theory, where the decisions of others, such as litigants or co-contractors, are taken into account when developing a strategy for one's own decisions, which will ultimately be reflected in the price of the traded commodity. ${ }^{33}$ For example, in a contract for the sale of land, the strategy for setting the price will require the sellers to consider whether or not they should incur the cost of investigating the full extent of legal encumbrances on that land, ${ }^{34}$ or whether it is safe to sell in ignorance of such restrictions in anticipation that the purchasers will also not investigate. This recognises each parties' desire to minimise their own informational costs in the absence of a contractual provision regarding mistake, for example, the hiring of surveyors or lawyers, which are typically associated with confirming the full value of the assets in one's possession. A seller could risk setting a price without investigating the actual worth of the property in the hope that it is accurate or if it is excessive that the purchaser will purchase in ignorance. The purchaser could in turn submit a lower bid, but the seller

30 E.g. Cook v Wright (1861) 1 B \& S 559 (the legal validity of the claim was weak but the claimants honestly believed that it was valid).

31 There is also strong policy against selling claims in that it brings the administration of justice into disrepute.

32 A goal which Bodey himself notes at para. 51.

33 Rasmusen and Ayres, "Mutual and unilateral mistake", n. 3 above, at p. 339 (in relation to mistake rules specifically). See also Cooter and Ulen, Law and Economics, n. 3 above, pp. 392-6, and Ogus, Costs, n. 7 above, pp. 23-4.

34 For example, the land may be subject to restrictive covenants or easements which may be unknown to both seller and purchaser during negotiations. This could equally be considered a question of fact. 
must then risk that this lower offer is a bluff and not a more accurate assessment of the land's true value based upon research. 35

Similarly, in choosing whether or not to settle, litigants will have to speculate as to whether their opponents have investigated the validity of a relevant legal principle. This may involve a further assessment of the resources which the opposing side have available to dedicate to litigation as well as whether there may be a cost-capping order or other judicial interference. The ex ante cost-benefit analysis of decisions to settle becomes that much more uncertain and therefore costly, as well as error-prone. Some contracting parties would view such tactical manoeuvring as a normal feature of the market and one which encourages the obtaining of socially productive information to improve one's chances of arriving at an efficient contractual result, but it also may operate as an impediment to settlement. Acknowledging mistake of law in a broader range of circumstances would appear to negate this type of behaviour. Although the cost of obtaining information would be minimised, uncertainty regarding enforceability would be increased. The ensuing litigation represents a cost to the civil justice system, warranting a strict approach to mistake of law.

\section{Mistake of law and contract externalities}

McKendrick and others suggest that the policy upon which the mistake doctrine is based is that there has been a failure of consent. ${ }^{36}$ Accordingly, it might be argued that there should be no resulting inefficiency by permitting a wide ambit for mistake of law because, with the true status of law revealed, parties are free to manifest their genuine consent through contract at some later stage. Moreover, a transaction resulting in a net loss because of a flawed misunderstanding, such as an insufficient quantum in a settlement agreement, is negated. ${ }^{37}$ Recognising that mistake of law will abrogate consent can also be seen as inefficient because through the voiding of contract the parties are returned to their precontractual position with the transaction costs of arguing mistake representing a loss. ${ }^{38}$ There is no resulting efficiency in an aggregate sense either ${ }^{39}$ since, again, the traded good remains in the hands of the party who held it to begin with. This is still the second-best solution to a fully informed contract because at least a negative-gain transaction is avoided.

Despite these outcomes for the parties themselves, contracting may result in effects felt by others or by society, so-called "externalities". In the context of mistake of law, the primary effect is the generation of legal knowledge. As noted above, by allowing relief through mistake of law to void settlement agreements, there will be no welfare improvement to society from the dissemination of an unknown feature of the law that could have formed part of the dispute at trial. This is because, with mistake of law readily available, contracting parties will not have an incentive to engage in legal research which can be used to consolidate their positions in the event of disputes. This lost information could have been reported for use by later litigants as precedent or be used to inform legal advice,

35 Subject to the limitation that sellers have the obligation to clarify any known misunderstanding on the part of purchasers or else a contract may be set aside for mistake, so-called unilateral mistake: Smith v Hughes (1871) LR 6 QB 597.

36 E McKendrick, Contract Law: Text, cases and materials 3rd edn (Oxford: OUP 2008), p. 529. See also Peel, Treitel, n. 25 above, at p. 310: “. . . mistake negatives consent where it puts the parties at cross purposes so as to prevent them from reaching agreement”; and E A Farnsworth, Alleviating Mistakes: Reversal and forgiveness of flawed perceptions (Oxford: OUP 2004), p. 124.

37 Rasmusen and Ayres, "Mutual and unilateral mistake", n. 3 above, at p. 339.

38 Thus, it does not satisfy Pareto efficiency which requires that neither party will be worse off and at least one party will gain. See Ogus, Costs, n. 7 above, pp. 26-9.

39 This is Kaldor-Hicks efficiency, see n. 7 above. 
lowering the risk of future costly claims by driving the law towards clarity. ${ }^{40}$ The truth of this assertion is predicated on the characterisation of information about the law as socially useful per se, unlike information about all other traded goods, for example, whether a painting is a genuine Constable or whether a certain car is an antique. Although ordinary factual information of this nature may in some circumstances benefit parties beyond the transaction at hand, such as all future purchasers or even art enthusiasts, in a welfareenhancing sense this does not compare to the benefit of legal information that is potentially of use to all members of society through the clarification of legal rights and obligations. Legal precedents may similarly be viewed as public goods, the availability of which improves compliance with the law and thereby reduces the burden on the state, for example, by reducing the need for police, as well as the reliance upon lawyers.

Nonetheless, wide ambit for mistake of law is problematic because it could lead to moral hazard; the taking of unnecessary risks in the knowledge that they can be shifted to others. With mistake of law readily available, future contracting parties will be less likely to inform themselves about prospective changes in the law that may have inconspicuously occurred before the conclusion of a contract because they know that if such a change is later revealed they will be able to backtrack on their obligations. Thus, we will expect that more claims of mistake of law will be made in relation to compromise agreements, which again represents an efficiency loss to the civil justice system by frustrating settlement in favour of costly trials. Still, it should be acknowledged that, unlike settlements, trials lead to the development and reporting of legal precedent and as such they represent a public good. Again this must be contrasted with mistake of fact where there is no such social utility because the facts of a particular dispute are likely only relevant to the parties at hand.

The acknowledged concern for third parties with respect to mistake in contract law is the injustice that may be brought upon good-faith purchasers who discover that a commodity was obtained under a subsequently void contract such that they lose their legal entitlement to goods for which they have paid. This problem should not apply with respect to mistake of law for contracts of compromise, as in Brennan, because claims cannot be sold as commodities to third parties by defendants. Still, others, such as shareholders of the public corporations involved in litigation, may act in reliance upon the settlement of a claim only to discover that the settlement agreement has later been voided for mistake of law, perhaps selling or purchasing their holdings under the misapprehension that further costly litigation had been avoided. ${ }^{41}$ The effect of litigation events therefore becomes a flawed signal for corporate performance, eroding investors' ability to gauge the value of shares, which should be viewed as an efficiency loss to society. ${ }^{42}$ The often-cited disadvantage suffered by third-party, good-faith purchasers should persist for contracts voided for mistake of law other than settlement agreements, such as those involving the exchange of real or moveable property for which legal restrictions are unknown.

With relief for mistake limited to exceptional circumstances, as indicated in Brennan, the legal profession may extract rents from clients by increased fees through prolonged litigation instead of settlement. Lawyers will, however, suffer from increased exposure to

40 The relevant legal information may be transmitted when mistake is argued in court, the judgment of which may be reported.

41 The announcement of litigation events has been shown to decrease share value of public corporations: L Weissenberger and L Stigsby, "Does misconduct matter? An investigation into the effect of litigation announcements on America's most successful companies", Stockholm School of Economics (3 February 2006), www.essays.se (last accessed February 2009).

42 Of course, a similar argument could as easily be made regarding the effects of the reversal of a judicial decision on appeal. 
professional negligence claims for failing to detect changes in the law which cannot be excused. This will represent a loss to their clients in the form of higher fees to offset the risk. This burden could be exacerbated by the fact that clients may honestly assert after the failure of their mistake of law claim that they would have paid for the extra research required to avoid the mistake if they had been properly informed that it might be needed, where in reality they would still have preferred a quick settlement to avoid the higher fee. ${ }^{43}$ More expensive legal fees will naturally cause the price of entering into contractual relations to rise. This represents a barrier to commerce generally and is, thus, against the interests of social welfare. In the case of commercial contracts between affluent parties we should not expect the effect of this increase in legal fees to be commercially prohibitive and the result might even be advantageous in that the risk of missing the narrow exception for mistake of law will encourage neglectful lawyers to practise their trade with greater caution, as long as excessive caution is not taken, which would be a waste of resources. ${ }^{44}$ Greater care might further improve the signalling expertise within an already competitive profession - the lawyers who are most fastidious are able to demonstrate this through higher fees, improving choice for consumers.

Principal-agent problems between solicitors and their clients could be exacerbated because without a broad mistake of law rule solicitors could legitimise greater billings for the purpose of legal research by reference to the unforgiving uncertainty of the law. This is especially so if they are paid by the hour and not on a conditional fee basis where the incentive to over-bill is most seductive. ${ }^{45}$ Research into the status of the law beyond that which is actually required to meet the clients' needs may represent a further cost to society because it contributes to the rise in the price of legal services, potentially undermining access to justice without a corresponding increase in the value of those services. In this way, mistake of law should be seen as advantageous because it discourages wasteful oversearching for informational advantage. ${ }^{46}$ This last point challenges the assumption that all legal information is necessarily beneficial, which, as Trebilcock has noted, may not be the case if the information is already widely known and can be transmitted at low cost. ${ }^{47}$

The Brennan court appears to envision that mistake of law will only be permitted in circumstances where society at large may benefit. Sedley notes the important role of public policy in determining when precisely the rule will apply. ${ }^{48}$ Maurice Kay similarly urges that exceptions to the rule that mistake of law is available in contract should be rooted in public policy. ${ }^{49}$ Accordingly, we should be mindful that Brennan's legally aided claimant solicitor commented that his decision to abandon the second dubious claim against Islington in exchange for the defendant's willingness to forego its right to costs against the claimant was based upon his duty to the Legal Services Commission (LSC) to minimise unnecessary costs. ${ }^{50}$ The degree to which litigation has received public financial support may inform the issue of public policy, in particular in relation to the value of the legal information which would have resolved the mistake. If the additional billed work that was necessary to clarify an ambiguity in the law represented a significant resource drain on public funds that was disproportionate to the benefit anticipated, courts may wish to countenance the omission

43 This phenomenon is known as "hindsight bias".

44 Smith and Smith, "Contract law", n. 3 above, at p. 468.

45 Larger uplifts could also be charged on a conditional fee to reflect uncertainty and/or risk.

46 Smith and Smith, "Contract law", n. 3 above, at p. 468.

47 Trebilcock, Limits, n. 5 above, at p. 112.

48 Para. 63.

49 Para. 23.

50 Para. 4. 
of such services by permitting the voiding of a contract entered into on the basis of inadequate knowledge. This is because the LSC will have already made its own assessment with respect to the potential public interest involved in a claim, often choosing to fund cases that may develop a novel point of law or raise an issue that affects the rights of society at large. ${ }^{51}$ This cost-benefit analysis should not be supplanted by a judicial determination in order to extend the use of public money for the purposes of generating information about the law. On the other hand, a clear public interest element should justify greater expenditure on research.

The obligation of greater research into the law necessitates a consideration of the role of law reporters as instruments of achieving the socially desirable goal of "equality of arms" in legal representation by permitting courts to lower the cost of controlling the risk of mistake. The imperfect availability of information regarding the law exacerbates resource asymmetry between contracting parties because some parties can afford to acquire this knowledge while others cannot, especially given the considerable expense of the more comprehensive private legal research databases such as Westlaw and Lexis-Nexis. With mistake of law operating only in exceptional circumstances such that few mistakes of law will be forgiven, it may be necessary for Parliament to consider improving the availability of legal information through the expansion of coverage of free online databases of caselaw, such as Her Majesty's Court Services, the subsidisation of non-profit organisations, such as the British and Irish Legal Information Institute, ${ }^{52}$ or the provision of private legal databases in public libraries. With legal information more readily available, we would expect mistakes of law to be less common.

The inference of causation between the lack of information-seeking activities and the resulting mistake may be fallacious because some of the legal information upon which contractual rights hinge is inherently unknowable, irrespective of resources. This is due to the nature of the legal profession as well as the uncertainty of the common law system. While counsel often rely on unreported decisions, it is not always possible to access all decisions in order to dispel mistaken assumptions about the law, especially given the volume of decisions and the time delay before some form of transcript is available. ${ }^{53}$ Further, it is important to recognise that in Brennan, as Wu rightly observes, the understanding of the law upon which the consent order was based could be proved by reference to non-privileged sources: the recorder striking out the claim against several co-defendants in the same action; the recorder basing her decision on another judgment that was later overturned; and the fact that the settlement was premised on the recorder's judgment. ${ }^{54}$ Were this information subject to strict professional privilege, a claim of mistake of law could not be substantiated, resulting in significant inequalities in terms of access to evidence between a claimant and defendant, as is often the case in a restitutionary claim for mistake of law. ${ }^{55}$ Of course, such privately held information might not properly be termed "legal" information, in the sense of it contributing to knowledge of the law itself as a precedent or statute would; further indication of the often blurred distinction between mistakes of law and those of fact. ${ }^{56}$ Balancing the mistake of law rule with professional privilege requires weighing the costs to

51 See the Legal Services Commission Funding Code, www.legalservices.gov.uk (last accessed January 2009).

52 See http://www.bailii.org (last accessed January 2009).

53 The reversed precedent upon which the Brennan decision turned was itself unreported.

54 T H Wu, "Legal professional privilege and restitution for mistake of law" (2004) 24 CJQ 246 at 254.

55 Ibid., at p. 257.

56 The distinction between mistake of law has been criticised heavily by commentators such as Peel, Treitel, n. 25 above, at p. 327, and often distorted, in e.g. Solle v Butcher [1950] 1 KB 671 where mistaken assumption about the applicability of the Rent Act was described as one of fact and law. 
society resulting from revealing otherwise unknowable information through the suspension of professional privilege against the transaction cost reduction of providing contracting parties with more complete information. Legal professional privilege should not be restricted unduly because of the important role confidences between solicitors and their clients play in the encouragement of settlement of civil claims by encouraging clients to consult legal experts without fear, as well as permitting litigants to conceal weaknesses in their respective cases. ${ }^{57}$

\section{Defining the optimal scope of the mistake of law rule}

The ambiguity of the Brennan judgment with respect to the delineation of the full extent of mistake of law has been observed by some commentators ${ }^{58}$ and can be equated with the flexibility of a standard rather than the certainty of a rule. ${ }^{59}$ While a standard allows some room for judicial discretion relating to issues such as public policy - which may reflect the fact that parties that have acted in good faith - it runs the risk of stirring future costly litigation because of the failure to articulate a more comprehensible and predictable outcome for all cases. Trebilcock in particular has warned that changing mistake rules to accommodate different circumstances is "hopelessly indeterminate operationally and likely to significantly exacerbate uncertainty, error and adjudication costs in contracting generally". 60 Thus, in light of some of the economic considerations canvassed above, a somewhat more focused rule will now be suggested. This is a modification of the rule first suggested by Rasmusen and Ayres that accommodates greater transaction costs in the dispelling of ignorance of the law because of the inherent value in all forms of legal knowledge, as distinct from certain types of factual information.

Relief based on mistake of law in contract should be tailored to the cost of the cheaper of either obtaining the necessary information or allocating the risk of mistake, relative to the loss engendered by the overall mistaken transaction, which in the case of compromise agreements will be the difference between the quantum of settlement and what would have likely been awarded at trial, taking into consideration what the trial itself would have cost. The last two variables will typically have a high degree of uncertainty but should not be beyond meaningful contemplation in what is meant to be an exercise of general balancing rather than mathematical computation. Limiting the availability of mistake to errors resulting from information that would have been excessively costly to correct under this analysis (through either information acquisition or risk allocation) is, perhaps unsurprisingly, the most efficient means of circumscribing the applicability of mistake of law in contractual relations. If the cost of offsetting the risk of mistake of law through contract were to affect the price of the traded good such that a transaction would not be completed (for example, if the settlement of a claim became prohibitively expensive because of the additional layer of stipulated risk, the settlement could be withdrawn given the discovery of a mistake) then a court should not expect a contracting party to include such a provision in a contract and mistake of law should accordingly operate in default. As an alternative to unreasonable pricing for risk avoidance through contract, the court should consider the cost of dispelling ignorance of the law. If the informational cost of obtaining the necessary information

57 This logic flows from the theory that the exchange of relatively positive information about one's case with one's opponent tends to cause the opponent to feel negatively about his or her own position which in turn promotes settlement: Cooter and Ulen, Law and Economics, n. 3 above, pp. 406-10.

58 Peel urges that tests need to be adapted for the mistake of law rule for contracts other than settlement agreements; Treitel, n. 25 above, at p. 326.

59 I Ehrlich and R Posner, "An economic analysis of legal rulemaking” (1974) 3 J of Legal Studies 257.

60 Trebilcock, Limits, n. 5 above, at p. 146. 
about a pertinent legal principle - for example, by paying a solicitor to engage in more comprehensive legal research - is so high that it would place an undue burden upon the party in question, assessed by reference to the profit expected from the transaction to that party (i.e. the quantum of a settlement), then the ensuing mistake should be forgiven. This is because the obtaining of the information itself would be inefficient, that is, the contract would result in a waste of resources because the process of contracting would exceed the wealth increase to the party and would therefore represent a sub-optimal outcome. ${ }^{61}$ Evidence relating to legal search fees and billings would be needed to make this determination, as would the size of the settlement and the likelihood of victory at trial - all of which are capable of at least rudimentary consideration by courts.

When assessing the cost of negating mistake through additional research, courts must further consider the inherent social value in the transmission of legal knowledge which is achieved by bringing claims to a trial which is ultimately reported, notwithstanding the fact that this knowledge may have represented an excessive transaction cost to the parties at hand and may have undermined a cheaper settlement conducted in ignorance. In keeping with the principle of Great Peace that only the most egregious of errors will be sufficient for a finding of common mistake, only those mistake-induced settlement agreements which are severely disproportional to that which would likely have been awarded at trial should be eligible to be voided, and then only if the cost of avoiding mistake is also high relative to the public interest in disseminating knowledge of the law. This should ensure that the law is diligently but reasonably investigated by solicitors and settlement agreements are not prohibitively uncertain. Such methodology broadly echoes conclusions observed by Farnsworth who pointed out that a rule of strict liability for mistakes of law is inferior to one based on a negligence standard because the value of learning the law is higher when the law excuses reasonable mistakes, since a person who takes such steps is protected against punishment even if one is mistaken in what one learns. ${ }^{62}$

\section{Conclusions}

A contracting party wishing to avoid liability for a mistake of law has three options:

- include a contractual provision which expressly allows relief from contractual obligations due to mistakes of law (which may either prevent the contract from being commercially feasible or negate the purpose of settlement);

- obtain the necessary legal information to achieve a reasonable degree of certainty about the status of the law in question;

- or do nothing and sue one's solicitor in negligence for failing to do either of the first two options (which would likely only be an available course of action were advice on these matters not provided from the outset).

When keeping these alternative courses of action in mind, courts should not expect contracting parties to suffer disproportionately high transaction costs because of the complexity of the legal system or the expense of obtaining information on the status of the law. Unlike the simple test from Great Peace, which established that the common mistake of fact will depend upon the severity of the error by reference to the contractual undertaking, mistake of law should be contingent upon the magnitude of the investigation or contractual risk avoidance that would have been required to avoid the misunderstanding in relation to the contract's resulting value, much as Rasmusen and Ayres originally theorised. Unlike for

61 In the Pareto sense, n. 38 above.

62 Farnsworth, Alleviating Mistakes, n. 36 above, at p. 140. 
mistakes of fact, this rule is subject to the crucial modification that even some inefficient contracts do generate social welfare because of the intrinsic value of legal information to a society. This rule is in keeping with economic reasoning in that it upholds contracts that are social welfare maximising and excuses those which are not.

While the developments in the law are perhaps now more complicated than ever, given the interplay of precedent in a myriad of courts and legislative instruments in the UK and $\mathrm{EU}$, it has also become increasingly easy (although perhaps no less expensive) to stay informed of these changes through advances in information technology relating to the law. At the same time the need to uphold settlement agreements as a means of avoiding costly litigation remains a primary objective of the civil justice system. The Brennan court's decision to limit the availability of the mistake of law defence only to what might be viewed as the most economically justifiable errors is consequently welcome. 
